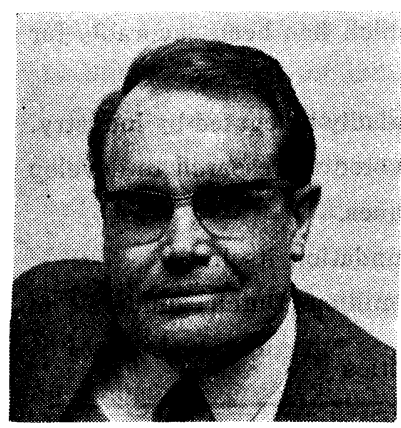

\title{
Scientific Industrial Service in Marine Technology
}

\author{
Prof. Dr. J. D. van Manen*
}

(Paper presented at a special lecture meeting of The Society of Naval Architects of Tapan in Tokyo on 26 November 1971)

\section{CONTENTS}

Introduction

1. Resistance and propulsion tests in the deep water tank

2. Cavitation

3. Vibratory forces induced by the Propeller

4. Software preparation for computeraided studies of shipowner opera. tion and shipyard production

$(1)$
$(3)$
$(5)$
$(6)$
$(8)$

(1)

( 3 )

(5)

( 8 )
5. The seakeeping laboratory

6. High speed towing tank

7. Shallow water basin

8. The wave and current laboratory

9. The ship manoeuvring simulator

10. The depressurized towing tank (vacutank)

Final consideration

References

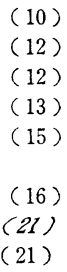

(10)

(13)

(15)

(16)

(21)

\section{SUMMARY}

Scientific industrial service in marine technology is dealt with. For the various aspects of this subject the activities of the Netherlands Ship Model Basin are taken as an explanatory example.

Due attention is paid to the hydrodynamics of ship hulls and ship propulsion, the oldest domains of industrial service of ship model basins. This includes research on hull forms with high block coefficients, different aspects of ship propulsion with regard to cavitation and propeller induced dynamic loads.

Motivations for building special purpose laboratories for specific problem areas are given. Especially for solving the problems of offshore technology, special purpose laboratories such as a seakeeping laboratory, a restricted waterdepth channel, a wave and current laboratory and a manoeuvring simulator are needed.

Some examples of industrial service in the field of computer aided ship design, shipyard production and shipowner operations are included.

In conclusion some considerations will be given about the initiative of designing and building a depressurized towing tank (Vacutank).

\section{Introduction}

Froude's and Tideman's ship model basins in the 19th century may be considered as the first scientific industrial service centers in marine technology. Their activities were primarily restricted to. the resistance and propulsion of ships, the oldest domain of marine research.

This lasted till around 1930, when “towing tanks" extended their investigations to tests in waves to determine hydrodynamic loads and ship hull excitation.

Examples of the excellent level of marine technology research carried out in the period 1930-1940. are presented in the German reviews "Hydromechanische Probleme des Schiffsantriebs" [1], [2] and in the proceedings of the International Towing Tank Conference [3].

The post "World War II"--developments in marine technology has been in some periods explosive. In this paper the author would like to deal with the growth of the Netherlands Ship Model Basin as. a representative example of the development in scientific industrial service in marine technology.

The Netherlands Ship Model Basin is an independent foundation on a non-profit basis. Its product. is a scientific technical report for the shipbuilding and shipping industry.

The style of management and the environmental condition of zero to minimum subsidy has promoted

* Managing Director of the Netherlands Ship Model Basin, Wageningen. 
a high scientific level and an industrial atmosphere, the combination of which has been favorable for the development of the N.S.M.B.

New fields of industrial service have been found in specialized activities, gladly delegated by industry.

Of the total activities of the model basin, about 25 percent has been devoted to research to develop new fields for industrial service and to improve existing laboratory techniques.

This research was financed by the government, the industry and the foundation itself.

The complex of laboratories of the N.S.M.B. represents a value of 24 million Dutch guilders ${ }^{1)}$ of

Table I List of the various N.S.M.B. testing facilities

\begin{tabular}{|c|c|c|}
\hline Name of facility & Dimensions in meters & Type of test \\
\hline 1. Deep water basin & $252 \times 10.5 \times 5.5$ & $\begin{array}{l}\text { Resistance, propulsion, vibratory } \\
\text { forces, etc. }\end{array}$ \\
\hline $2^{\mathrm{a}}$. Large cavitation tunnel & $0.9 \times 0.9$ (test section) & $\begin{array}{l}\text { Cavitation tests with propellers, profiles } \\
\text { etc., in various types of flows; fluctuat- } \\
\text { ing pressures on hull. }\end{array}$ \\
\hline $\begin{array}{l}2^{\mathrm{b}} \text {. Cavitation tunnel with flow } \\
\text { regulator }\end{array}$ & $\begin{array}{l}0.4 \text { circular test sec- } \\
\text { tion }\end{array}$ & $\begin{array}{l}\text { Cavitation tests with propellers in sim- } \\
\text { ulated axial wake. }\end{array}$ \\
\hline 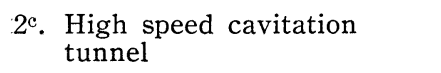 & $\begin{array}{l}0.04 \text { circular test sec- } \\
\text { tion }\end{array}$ & For fundamental cavitation study \\
\hline $\begin{array}{l}\text { 3. Computer centre (CDC } 3300 \\
\text { computer, } 2 \text { paper tape } \\
\text { drawing machines) }\end{array}$ & & $\begin{array}{l}\text { Hydrostatic, stability, trim ,etc. calcu- } \\
\text { lations. Scale drawings for optical- } \\
\text { following flame cutters. Design of } \\
\text { ships, including economic calculations. }\end{array}$ \\
\hline 4. Seakeeping laboratory & $100 \times 24.5 \times 2.5$ & $\begin{array}{l}\text { Ship motion measurements; necessary } \\
\text { power increase to maintain speed; bot- } \\
\text { tom and deck pressures; water ship- } \\
\text { ment and screw racing; wave-induced } \\
\text { shear forces, bending and torsional mo- } \\
\text { ments; measurements on semi-submer- } \\
\text { sibles etc. All in regular and irregular } \\
\text { waves. }\end{array}$ \\
\hline 5. Shallow water basin & $216 \times 15.75 \times 1.25$ & $\begin{array}{l}\text { Resistance and propulsion in shallow } \\
\text { water; squat and trim measurements; } \\
\text { transverse forces, yawing moment and } \\
\text { rudder torque on captive model; resist- } \\
\text { tance and performance in waves; ship } \\
\text { motions in regular and irregular waves; } \\
\text { motions, mooring and anchorline forces } \\
\text { of semi-submersibles or moored struc } \\
\text { tures; oscillating tests; manoeuvring } \\
\text { tests, etc. }\end{array}$ \\
\hline $\begin{array}{l}\text { 6. Wave and current labora- } \\
\text { tory }\end{array}$ & $\begin{array}{l}60 \times 40 \times 1.20 \text { (water- } \\
\text { depth is variable) }\end{array}$ & $\begin{array}{l}\text { Determination of feasibility of vesse } \\
\text { configurations, with respect to waves, } \\
\text { current and wind; motion and force } \\
\text { measurements; spiral and turning cir- } \\
\text { cle tests; tests in harbour models, etc. }\end{array}$ \\
\hline 7. High speed towing tank & $220 \times 4 \times 4$ & $\begin{array}{l}\text { Testing planing hulls; high speed pro- } \\
\text { pulsion devices; ice breaking studies in } \\
\text { simulated ice fields. }\end{array}$ \\
\hline $\begin{array}{l}\text { 8. Manoeuvring simulator } \\
\text { (hybrid computer) }\end{array}$ & & $\begin{array}{l}\text { Training in ship handling; development } \\
\text { of navigational aids; design of harbour } \\
\text { entrances; development of criteria for } \\
\text { manoeuvring, etc. }\end{array}$ \\
\hline 9. Depressurized towing tank & $240 \times 18 \times 8$ & $\begin{array}{l}\text { Resistance, propulsion and propeller } \\
\text { cavitation tests; flow visualization tests; } \\
\text { wave breaking phenomena at the bow; } \\
\text { wake surveys; propeller-induced vibra- } \\
\text { tory forces in shaft and on hull; acous- } \\
\text { tical measurements; etc. }\end{array}$ \\
\hline
\end{tabular}

1) Not corrected for devaluation: The value of the insured capital is 33 million Dutch guilders, excluding site, sewerage and basements. 
which 17 percent has been granted by government and industry, 50 percent has been paid from the revenues obtained for industrial service and 33 percent still remains as a bank loan.

The vacutank under construction requires an investment of 32 million Dutch guilders, which capital was financed by banks under a government guarantee.

The laboratory staff consists of 330 persons in total, of which 65 have a higher professional education.

In Table I a review is given of the existing facilities with their dimensions and capabilities.

In the beginning the development of the N.S.M.B. originated in the large and increasing number of industrial orders in the deep water towing tank. This burden of work led the management to consider it wise to design and construct special purpose laboratories to unload the daily pressure $\mathrm{cn}$ the capacity of the deep water tank. This led to the building of the following laboratories: the seakeeping laboratory (1956), the shallow water basin (1958) and the high speed basin (1965).

In order to meet the demand for advanced industrial service the following facilities were built: the cavitation tunnel with non-uniform flow simulation (1956), the wave and current laboratory for offshore problems (1965), a computer center for shipbuilding and shipping industry (1961), the manoeuvring simulator (1970) and finally the depressurized towing tank (vacutank) (1972).

The activities in these N.S.M.B.-laboratories will be reviewed and illustrated in the following sections.

\section{Resistance and propulsion tests in the deep water tank}

Over 4000 ship models and propellers have been tested in this facility.

Troost initiated a "first results: three weeks after receipt of the drawings"- -service. Koning and Muntjewerf realized and maintained this approach of industrial service, which has been and still is an important base for the good relation between laboratory and industry.

During the 40 years of existence of the deep water towing tank, important initiatives for research and development were taken. Within the scope of this review it may be permitted to memorize the following topics.

Van Lammeren derived from Baker's results the Wageningen-systematic screw series and plotted the results of the test series in suitable diagrams [4] for industrial applications. In the course of the years, these Wageningen screw series have been continuously extended. In Table II the available series are given. Oosterveld developed a "cross-fairing" program for the computer and recently all available Wageningen screw data were computer-faired with respect to the advance coefficient, pitch ratio, blade area ratio and blade number. An improved Lerbs equivalent radius method was used to include the effect of Reynolds number [5], [6].

A contribution to the research into the scale effect in the propulsion components was given by Van Lammeren in studies of the Simon Bolivar and Victory geosim-series [7], [8], [9]. The 22 metcr

Table II Summary of the Wageningen $B$-screw series

\begin{tabular}{|c|c|c|c|c|c|c|c|c|c|c|c|c|c|c|}
\hline $\begin{array}{c}\text { Blade } \\
\text { number } Z\end{array}$ & \multicolumn{14}{|c|}{ Blade area ratio $A_{E} / A_{0}$} \\
\hline 2 & 0.30 & & & & & & & & & & & & & \\
\hline 3 & & 0.35 & & & 0.50 & & & .065 & & & 0.80 & & & \\
\hline 4 & & & 0.40 & & & 0.55 & & & 0.70 & & & 0.85 & 1.00 & \\
\hline 5 & & & & 0.45 & & & 0.60 & & & 0.75 & & & & 1.05 \\
\hline 6 & & & & & 0.50 & & & 0.65 & & & 0.80 & & & \\
\hline 7 & & & & & & 0.55 & & & 0.70 & & & 0.85 & & \\
\hline
\end{tabular}


modelboat D.C. Endert (Victory ship, scale 1:6) delivered basic and sometimes controversial data for "extrapolator"--specialists. Basic, regarding the scale effect in the wake factor, see Fig. 1, controversial, regarding the scale effect in the thrust deduction factor.

Lap analyzed both geosim series and proved empirically the validity of his $\log A$-method for all practical purposes. By intoducing a form factor $\Delta \log A$ a "ship form frictional drag" curve could be derived from a "flat plate" curve [10].

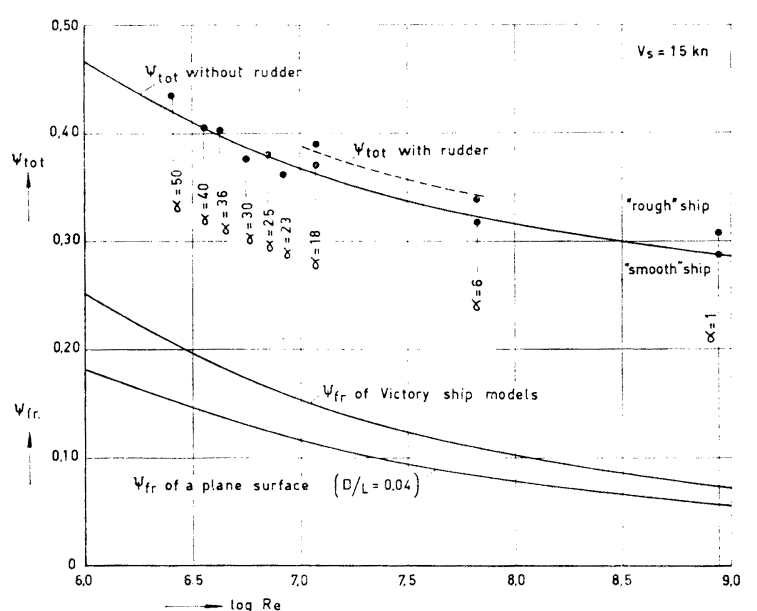

Fig. 1 Scale effect in wake factor of the Victorygeosims.

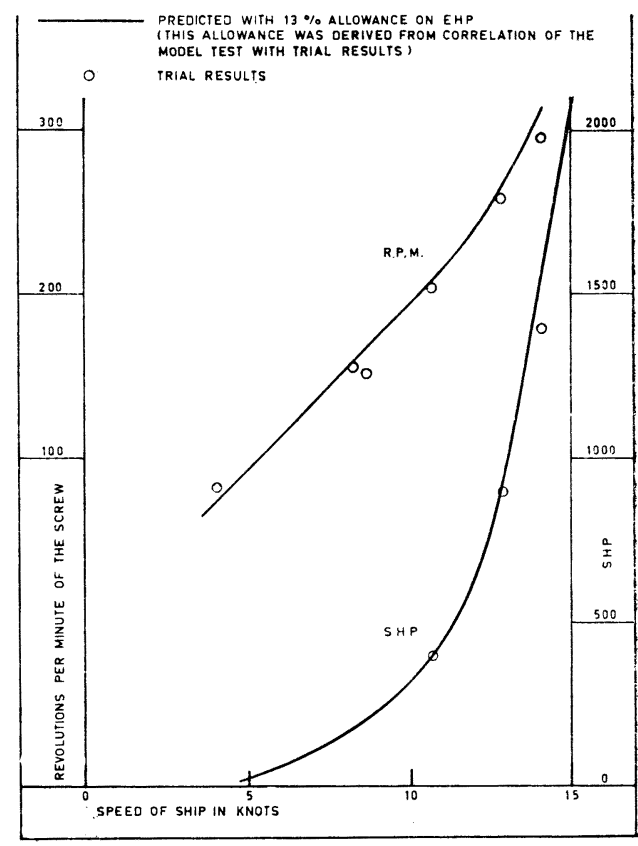

Fig. 2 Comparison of predicted and measured trial results of pilot boat.

Another contribution of Lap was his analysis of available N.S.M.B. resistance test data. His dimension analysis of ship form parameters led to instructive diagrams for the determination of ship resistance [11]. The introduction of the computer in the field of data reduction led Van Oortmerssen to evaluate polynomials for available resistance data [12], see Fig. 2.

In the field of wave resistance theory Timman, Vossers and Joossen complemented the "thin ship" theory (Havelock, Weinblum, Wigley) with the slender body theory.

Van Manen introduced the screw-nozzle system as one undividable propeller unit and produced de-

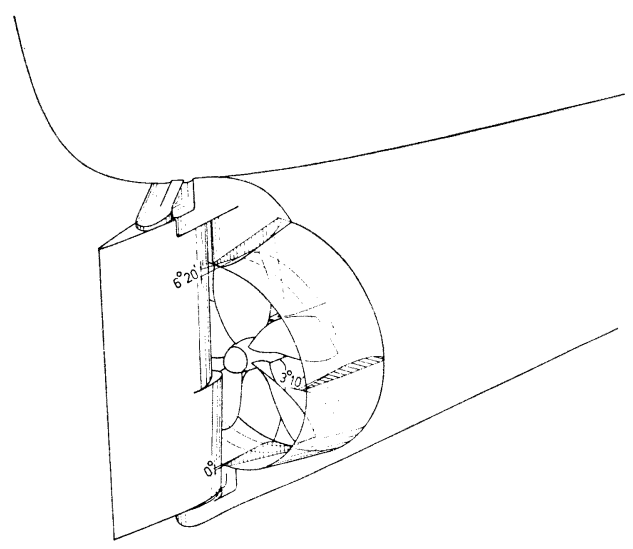

Fig. 3 View of stern of tanker fitted with non-axisymmetrical ducted propeller. sign diagrams for this unconventional propeller type [1.3], [14].

These test data solved many design problems and formed a start for the application of ducted propellers to larger ships. Besides, an impulse was given to the development of ducted-screw theories.

Recently Oosterveld [15] introduced the non-axisymmetrical wake adapted nozzle, see Fig. 3 . Reductions in required shaft horse power 5 to 12 percent have been obtained in the application of the ducted-screw to tanker models. In the case of a restriction of the screw diameter or the screw weight, even higher reductions have been reached. for large tankers. 
The development of bulb and cylindrical bows for ships with very high block coefficients have been favorably effected by systematic bow studies. Muntjewerf reported on the results of systematic investigations performed at the N.S.M.B. [16], [17], some of which are given in Fig. 4.

\section{Cavitation}

The large cavitation tunnel of the N.S.M.B., designed by Lerbs, was followed up by a smaller cavitation tunnel with a flow regulator for wake-simulation. With this cavitation tunnel, the N.S.M.B. has had much experience and obtained a vast knowledge of propeller cavita-

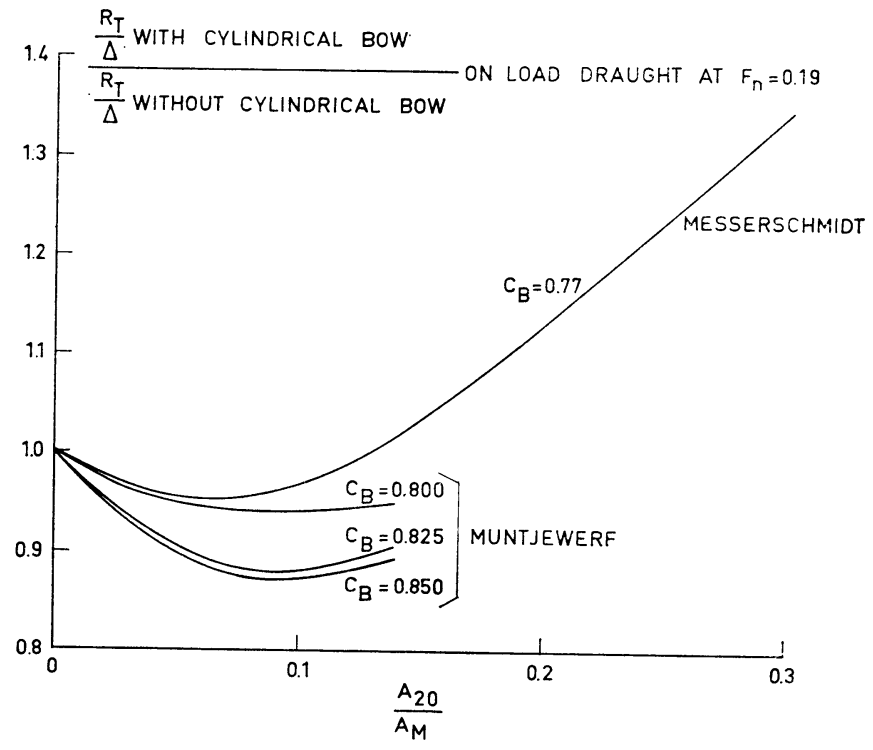

Fig. 4 The effect of block coefficient $C_{B}$ on the improvements in specific total resistance as a function of the cylindrical bow area coefficient $A_{20} / A_{M}$.

tion phenomena in ship wakes. Developments in lifting line and lifting surface theory were in this way evaluated to obtain practical design knowledge. It became possible to secure criteria for the optimum selection of pitch angles and profile-camber from the view-point of a required $\mathrm{rpm}-V_{s}$ relation and a minimum risk of cavitation damage.

An example of the obtained knowledge and experience of cavitation phenomena in a non-uniform wake is Van Manen's explanation of the bent trailing edges of screw blades and the indications as to how to prevent this cavitation damage [18]. The theoretical justification of this explanation was given by Van Wijngaarden [19].

Contributions to the fundamental aspects have been presented by Van der Walle on the growth of nuclei and the related scaling factors in cavitation inception [20] and by Van der Meulen on the significance of surface and stream nuclei [21], see Fig. 5, and on the characterization and determination of erosion resistance [22], see Fig. 6.

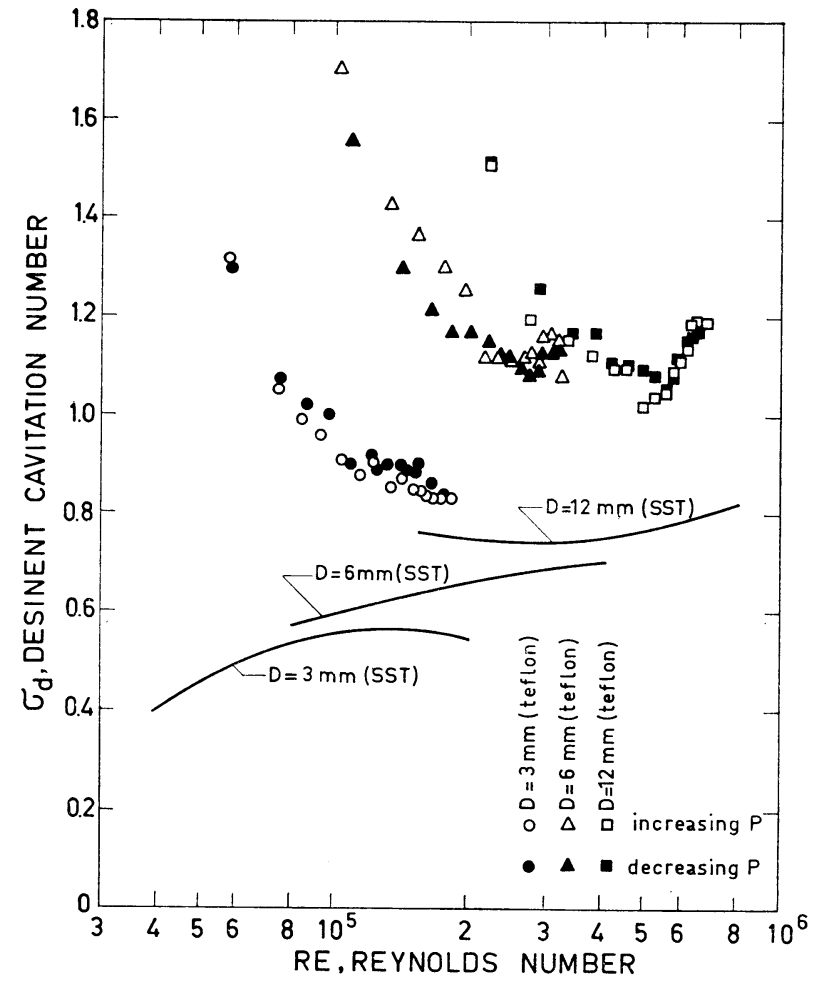

Fig. 5 Desinent cavitation number versus Reynolds number for teflon models and stainless steel (SST) models. 


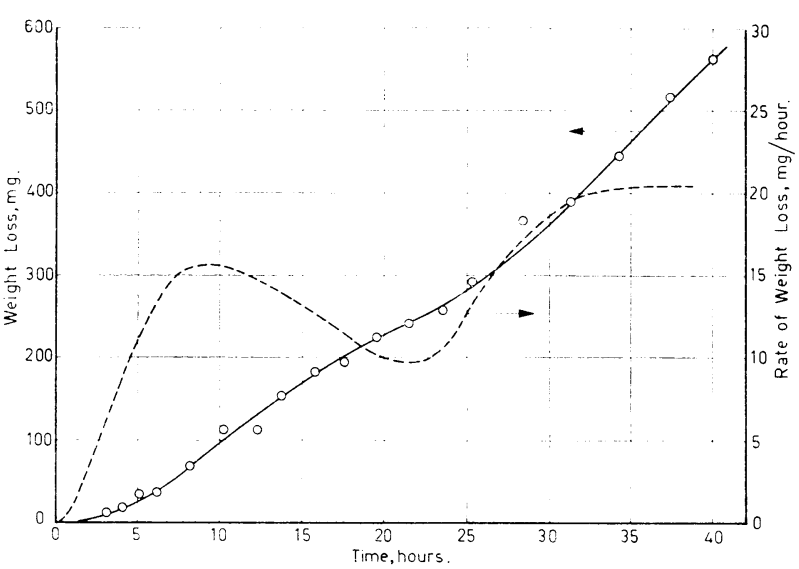

Fig. 6 Effect of time on weight loss and rate of weight loss of propeller model due to cavitation erosion.

Van Oossanen reanalyzed Balhan's measurements, on two dimensional profiles in cavitating and non-cavitating conditions [23]. This analysis can form the basis for designing profiles and propellers, promising from the view-point of vibrations and noise reduction [24].

A substantial support in the understanding of the complex problem of the cavitating propeller in a non-uniform flow has been delivered by the theoretical studies based on lifting surface theory. Though a rigorous lifting surface theory for ship screws in a nonuniform flow including cavitation phenomena has not been obtained, important progress is being achieved.

Sparenberg developed a sound lifting surface theory for ship screws in a uniform flow [25]. Van Manen and Bakker gave numerical results based on that theory. Some of these results were controversial with results obtained by other theories and received scepticism.

Sparenberg and Verbrugh extended the theory for non-uniform flows [26]. Kuiper reported on numerical results of calculations comparable with other theories [27]. However, as said before, the introduction of cavitation phenomena in this theory is essential for a fruitful symbiosis between experimental investigations and theoretical computations.

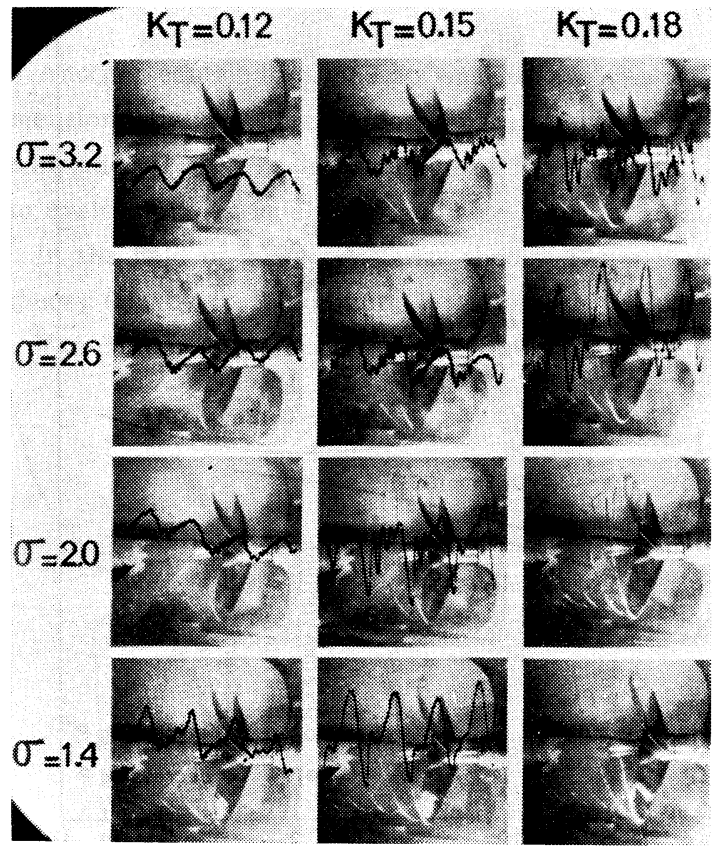

Fig. 7 Example of results obtained of fluctuating pressure measurements on built-in afterbody in cavitation tunnel: note the influence of cavitation.
Recently Van Manen presented the results of an investigation into the effect of cavitation on the pressure fluctuations at the stern excited by the propeller. The increase of these pressure fluctuations on the ship's after-body by propeller cavitation was found to be considerable [28], see Fig. 7. The discovery of these phenomena may be explanatory for the vibration casualties at the stern and will lead to new design criteria for the blade tips [29].

\section{Vibratory forces induced by the pro- peller}

Important progress in our knowledge of the dynamic components of a propeller in a nonuniform wake was booked by Wereldsma [30], [31]. Wereldsma designed and realized a six component dynamometer for ship propellers. His greatest difficulty, the bad signal-noise ratio, was overcome by developing a sampling technique, based on the assumption that the frequencies of the force fluctuations are equal 


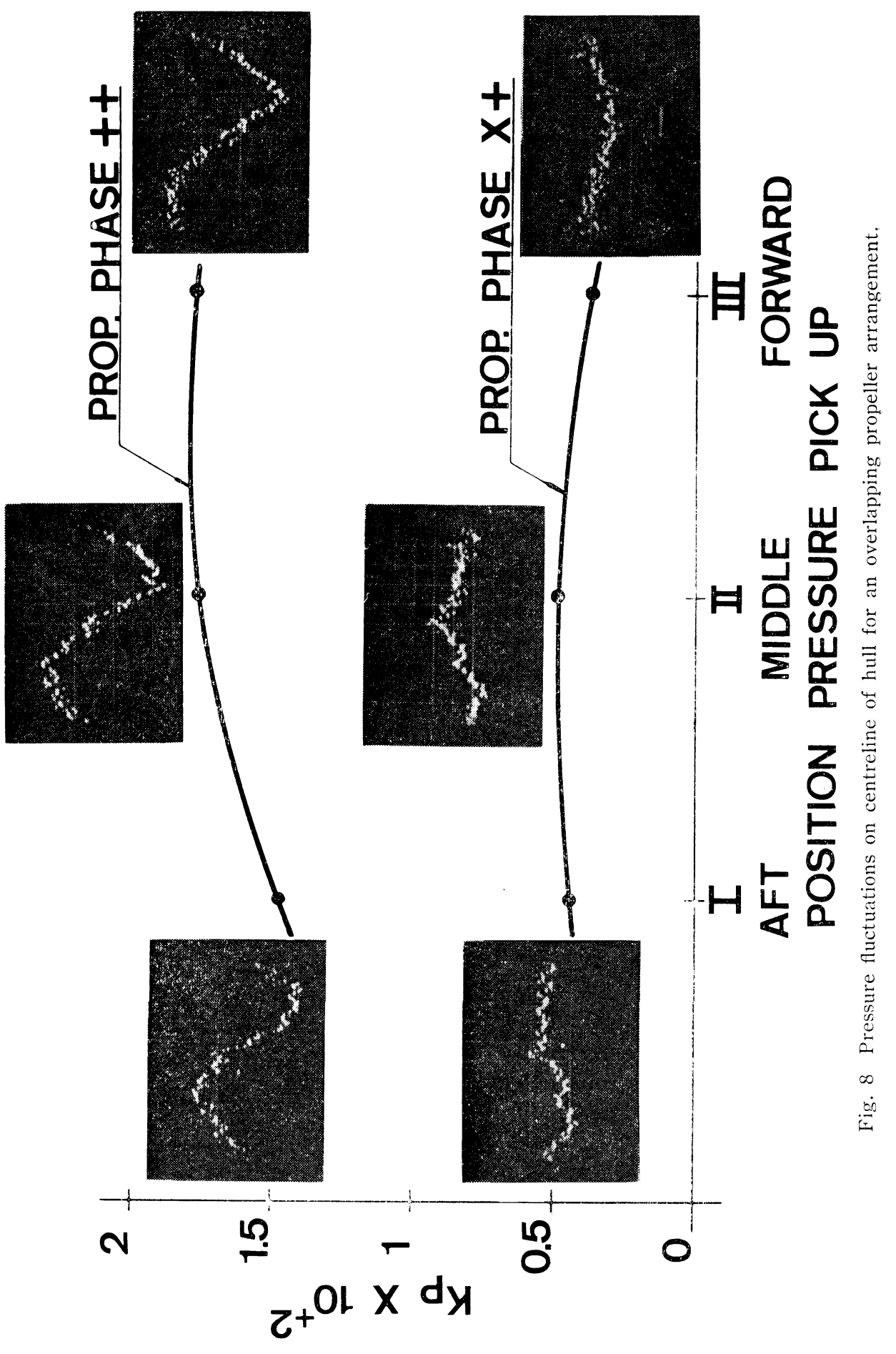


to the number of revolutions times the number of blades (blade frequency) or a multiple thereof.

Wereldsma also developed a propeller exciter to evaluate the hydrodynamic mass, damping and the hydrodynamic coupling between thrust and torque vibrations. In this way he was able to solve the coupled differential equations of the screw-shaft-thrust block system and reach a good correlation between his predictions of the torque and thrust fluctuations based on model test data and the results of measurements on the full size ship [32].

After this successful penetration into the dynamics of axial shaft behaviour Wereldsma and Hylarides started investigations into the field of transverse excitation of the afterbody and hydrodynamic induced pressure fluctuations at the stern. This research was carried out for conventional screw propellers, ducted propellers, overlapping propellers (see Fig. 8) and contra-rotating propellers.

Hylarides introduced a finite element method, including the effect of shear stresses and advanced the interpretations of hydrodynamic mass, damping and coupling in hull vibration analysis [33]. A result is shown in Fig. 9.

The stress analysis of propeller blades rotating in a non-uniform flow based on the results of model and full scale experiments is being complemented by a structural propeller blade analysis by finite element technique. Perfection of this theoretical approach is still necessary as is also a reliable input, derived from a rigorous lifting surface theory for non-uniform flow including cavitation phenomena.

\section{Software preparation for computer-aided studies of shipowner operations and shipyard production}

When the N.S.M.B. introduced the computer into their hydromechanic research and for data reduction of model test results, a possibility for a new type of industrial service was born: the software preparation for computer-aided studies of shipowner operations and for shipyard production.

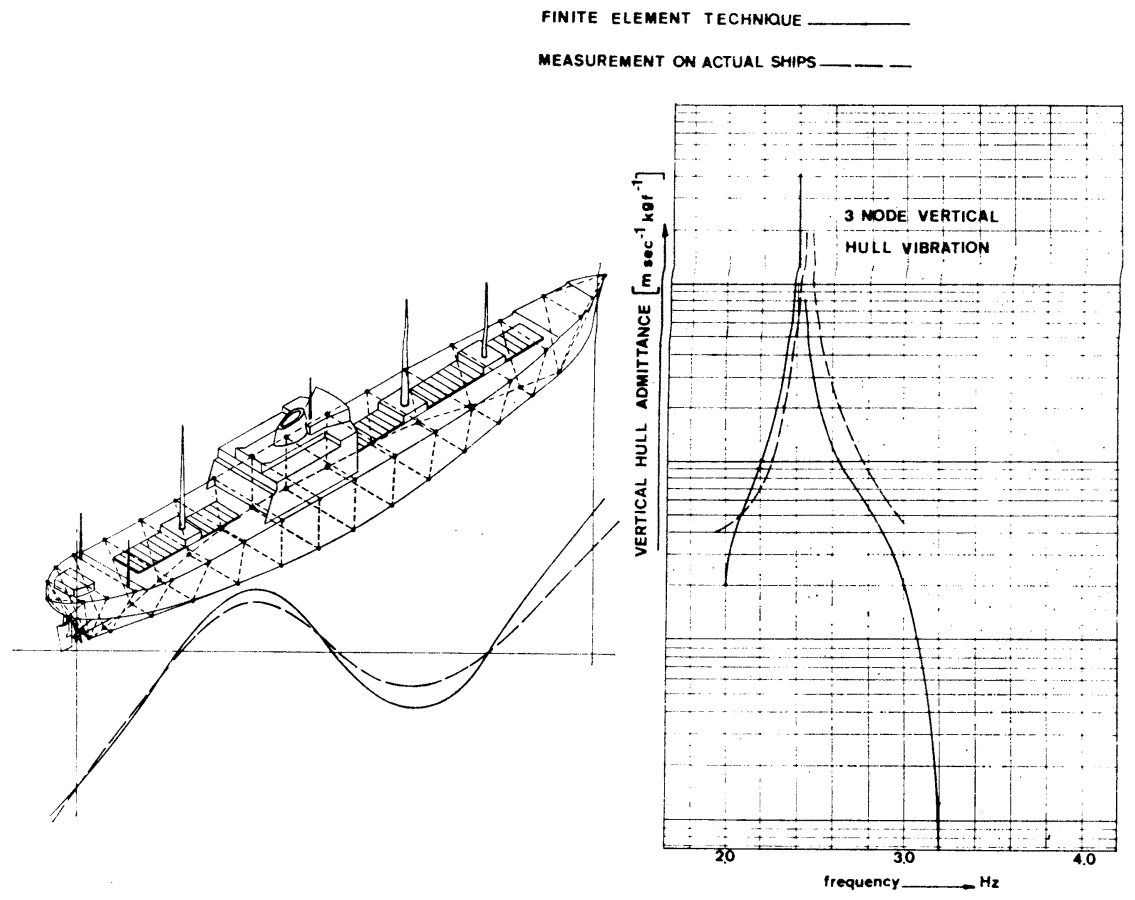

Fig. 9 Forced hull vibration analysis by finite element technique. 
After the realization of programs for the usual set of bydrostatic calculations more advanced mathematical studies were initiated.

Via the fairing of ship lines and hull plate development Bakker developed a Numerically Adapted Language for Shipbuilding (N.A.L.S.), an integrated system of computer programs for shipyard production.

Paper tape preparation was realized for a numerically controlled propeller model milling machine and for numerically controlled drawing systems. The drawings and paper tapes are used for optical or numerically controlled flame cutters respectively.

Programs for the preliminary design of cargo ships, bulkcarriers and coasters have also been developed. With these design programs parametric studies and ship operation simulation can now be performed, see Figs. 10 and 11. This has been done for high speed boats with emphasis on the selection of the propulsion devices, see Fig. 12, and for bulkcarriers with alternative routes (see Fig. 13).

Finally, sophisticated design studies such as the study of a restricted draft tanker and of special ship-type application as alternative links of various transport chains were carried out.

The restricted draft tanker is a typical example of integrated ship design, including an optimized harbour depth [34].

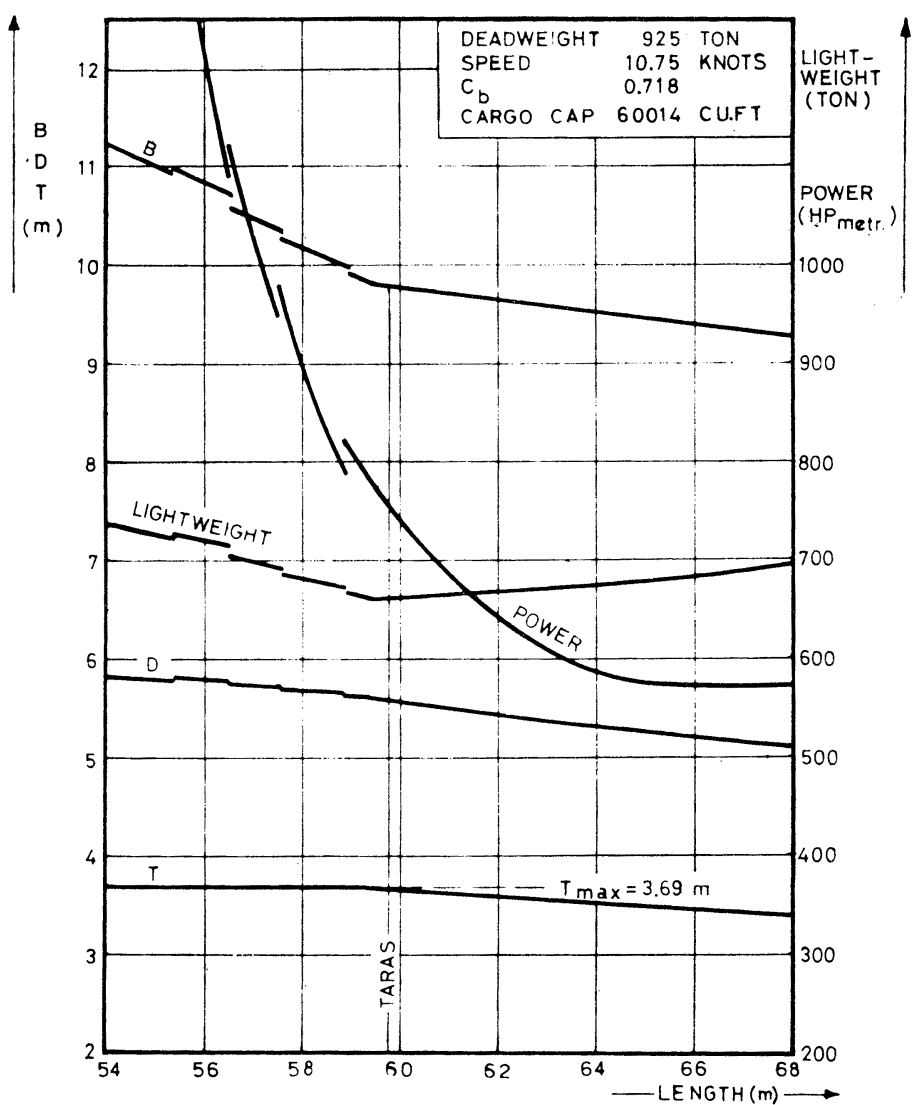

Fig. 10 Length variation study of the coaster TARAS: results of technical parameters. 


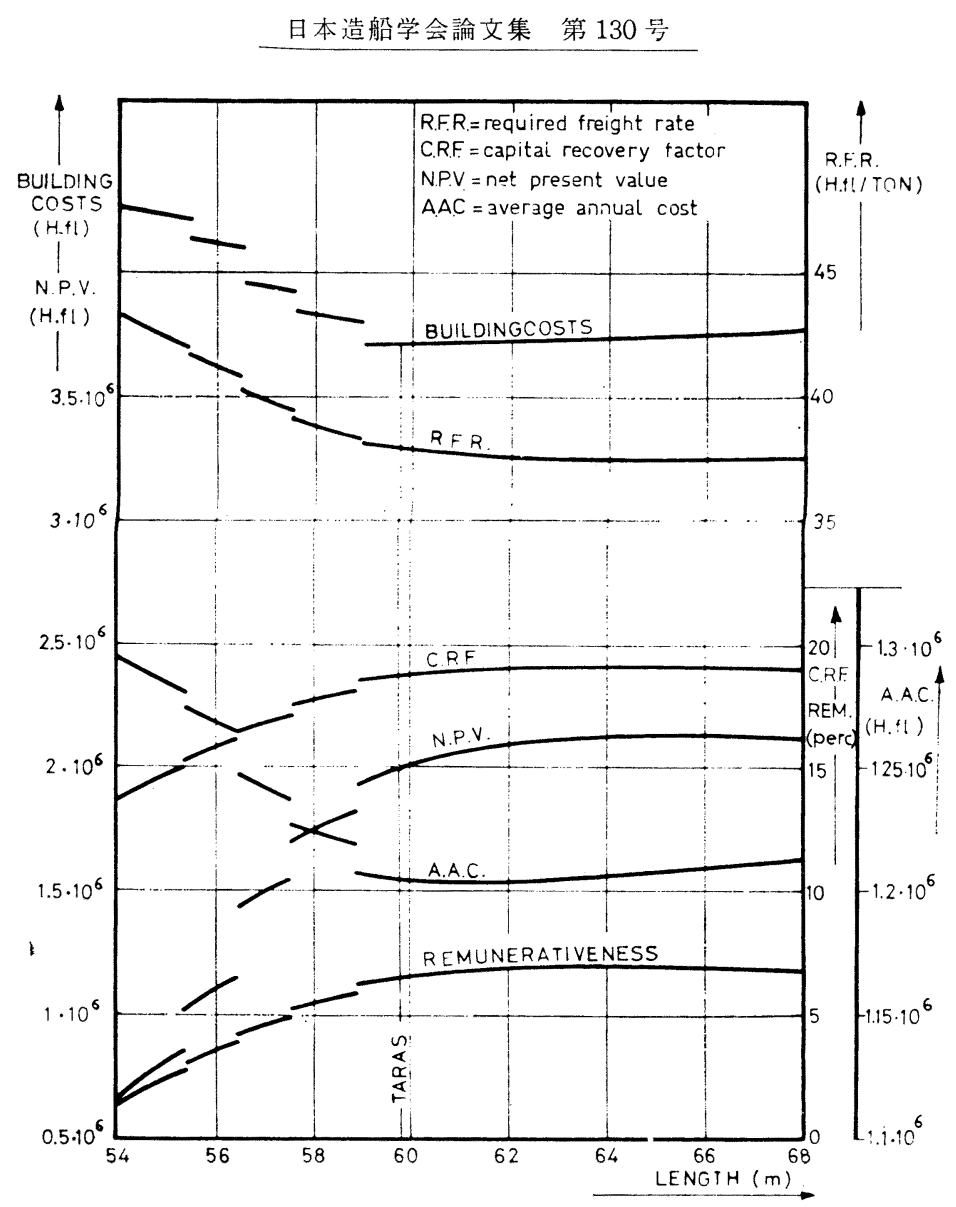

Fig. 11 Length variation study of the coaster TARAS: results of economical parameters.

\section{The seakeeping laboratory}

In 1955 the N.S.M.B. decided to build a seakeeping laboratory in which both oblique and irregular seas could be simulated.

Sogreah's wavemaker of the snake-type was the essence, around which this special purpose laboratory has been designed. A compromise between avoiding large scale effects in the flow around the hull and to avoid high loads on the model hull was obtained by selecting model lengths between 3 and $4 \mathrm{~m}$ for the self propelled models.

The first research in this laboratory was an extensive systematic investigation of the 60-series [35]. The effect of the main hull form parameters on the behaviour in a seaway could be determined.

Based on experience of different types of tests in the seakeeping laboratory and a large bibliographical knowledge, Vossers wrote his reviewing book on the behaviour of ships in a seaway [36].

Swaan reported on the systematic test results of horizontal and vertical ship bending moments and torsional moments in order to obtain design data [37].

Experimental slamming studies were endorsed by the theoretical studies of Verhagen [38].

The predictions made by Van Sluijs for deck wetness, derived from model tests, see Figs. 14 and 15, showed a striking correlation with full scale observations [39].

Broaching, speed loss and roll stabilization tests are other examples of research in this seakeeping 


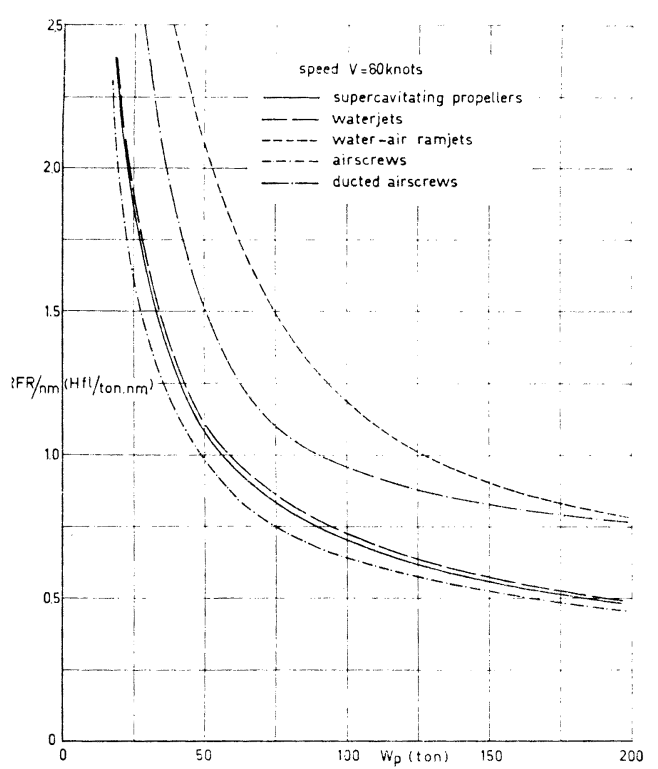

Fig. 12 Economics of a hovercraft fitted with different propulsion devices designed for a speed of 80 knots.
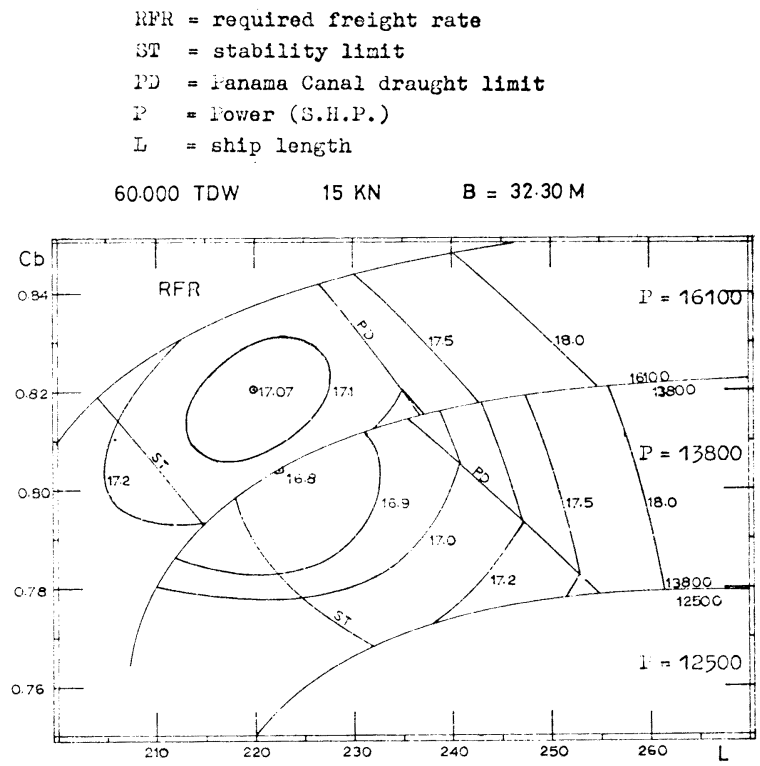

Fig. 13 Economics of bulkcarrier of fixed breadth and deadweight tonnage on a given trade route.
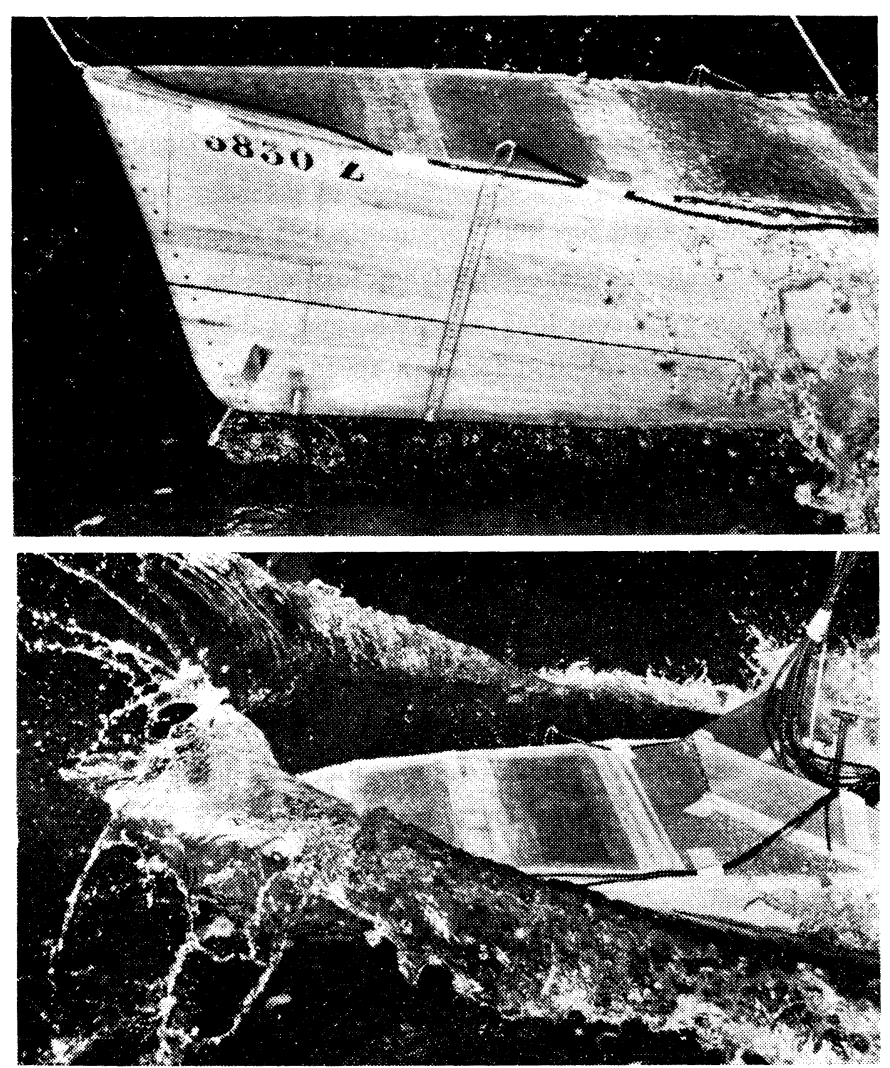

Fig. 14 Photos of ship model undergoing simultaneous bottom pressure, slamming, deck wetness and deck pressure test. 


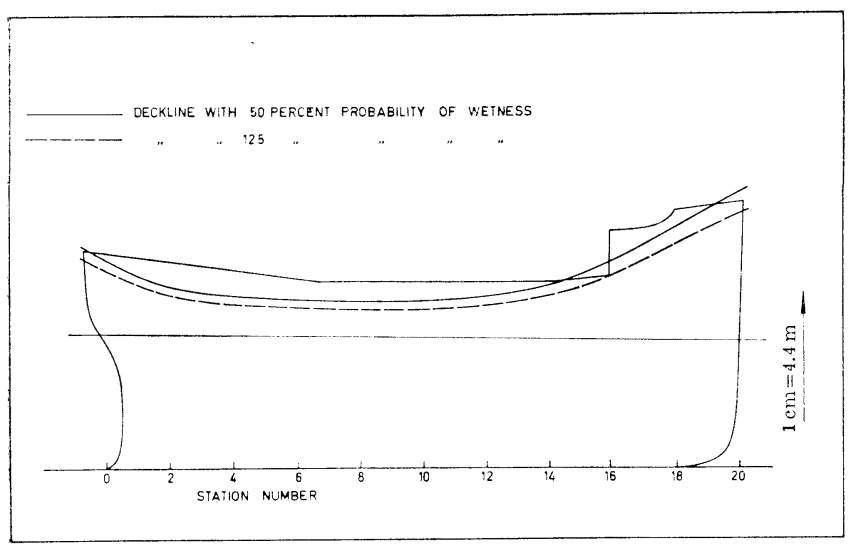

Fig. 15 Deck lines of specified probability of wetness for a Beaufort 8 headsea. laboratory which improve the scope and value of industrial service performed by the N.S.M.B.

Recently the type of investigations ordered by industry has been changing. Feasibility studies of non-conventional design concepts in irregular and oblique seas increase in number, e.g.:

- seagoing tugs with non-conventional tows as drilling rigs,

-air cushion boats,

-tug and barge systems,

- single point mooring systems,

-drilling rigs and ships for relatively deep water.

\section{High speed towing tank}

For the sake of completeneess, the existence of a high speed tank with a cross section of $4 \times 4 \mathrm{~m}^{2}$ and a length of $220 \mathrm{~m}$, may be mentioned.

This facility is equipped with two carriages, one conventional up to $15 \mathrm{~m} / \mathrm{sec}$. and one unmanned, waterjet driven, up to $30 \mathrm{~m} / \mathrm{sec}$.

The unmanned carriage has been applied for tests with high speed propulsion devices such as water-air ramjets [40], struts and hydrofoils. The conventional carriage up to $15 \mathrm{~m} / \mathrm{sec}$. is used for planing hulls.

Moreover, this facility has been used for time consuming test programs so that other facilities such as the deep water towing tank and the seakeeping laboratory can be used more efficiently.

Complicated test arrangements requiring long assemble and calibration time can be examined in this facility, which is not permanently applied for high speed work.

Ice breaker studies in simulated ice fields and the analysis of various types of swim strokes are other examples of miscellaneous experimental research carried out here.

\section{Shallow water basin}

After the test program of the Rhine tanker "Arabia" it became clear that model tests carried out in shallow water, simulated by an adjustable false bottom, leads to meaningless data. The N.S.M.B. therefore decided to build a shallow water basin with a width of $16 \mathrm{~m}$, especially after obtaining the favorable results of a market analysis in the Mississippi area. There was a large need for a special purpose laboratory for the investigation of push-towing. Fleets of barges of up to 32 units have been tested in integrated and semi-integrated tows. Optimization of the bow and stern form of barge units and of afterbody configurations with 2 , or even 3 , ducted propellers and flanking rudders have been shown to lead to high-quality push-towing systems.

Lap analyzed the results of the Arabia geosims and of the many industrially ordered test programs. His form factor interpretation, a $\log A$-shift of the flat plate curve in the $\log R e$-direction showed the best correlation between model test results and full scale measurements in shallow waters [41].

Hooft contributed to our insight of critical wave phenomena in shallow water [42].

With growing activities in the field of the offshore industry and with increase in tanker size, the 
scope of work in the shallow water basin changed.

Single point mooring systems in shallow water, drilling rigs in shallow water, fundamental studies of forces on cylinders, see Fig. 16, under water oil storages etc., introduced a new atmosphere in test work in the shallow water basin.

A wavemaker had to be installed to meet the customers requirements.

Trim and squat measurements for tankers approaching restricted water had to be carried out with and without waves. Captive model tests had to be carried out to define the coefficients of the equation of motion in a horizontal plane.

The high demand for the present-day type of industrial service in marine technology, especially in all problems around coasts and harbours, led to the design and construction of a wave and current laboratory.

\section{The wave and current laboratory}

This laboratory, described by Van Lammeren and Lap [43] has been designed especially for industrial projects. A basin of $40 \times 60$ square meters in which irregular waves in all directions, currents and winds could be simulated was considered the ideal basin to investigate the feasibility of designs for drilling, mooring, dikes, launching, improving harbours, transfer of cargo in open sea from a large tanker into a smaller one, mooring of containerships at their terminals, etc.

After a period of very intensive industrial research in this wave and current laboratory, the companies active in the field of offshore-technology hesitated. Many "ad hoc", though promising designs had been carefully investigated, but not led to the expected results. Another approach than the "ad hoc" approach was needed.

Hooft [44] provided for such an approach by dividing the complicated construction of drilling rigs, see Fig. 17, into elementary units, of which he was able to determine the hydrodynamic properties.

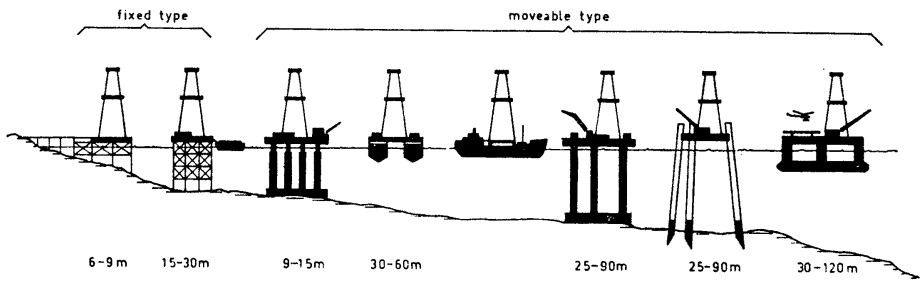

Fig. 17 The various types of drilling platforms.

He neglected interaction effects and superimposed these units again to the complicated construction. The correlation between the prediction based on his "superimposed unit system" and the full scale results was very striking, see Fig. 18. The computer program evaluated from this idea of this superposition of elementary units is an adequate tool for selecting and qualifying preliminary designs of complicated drilling rig constructions. In this way only the best of some design configurations can be tested and disappointments can be avoided. 


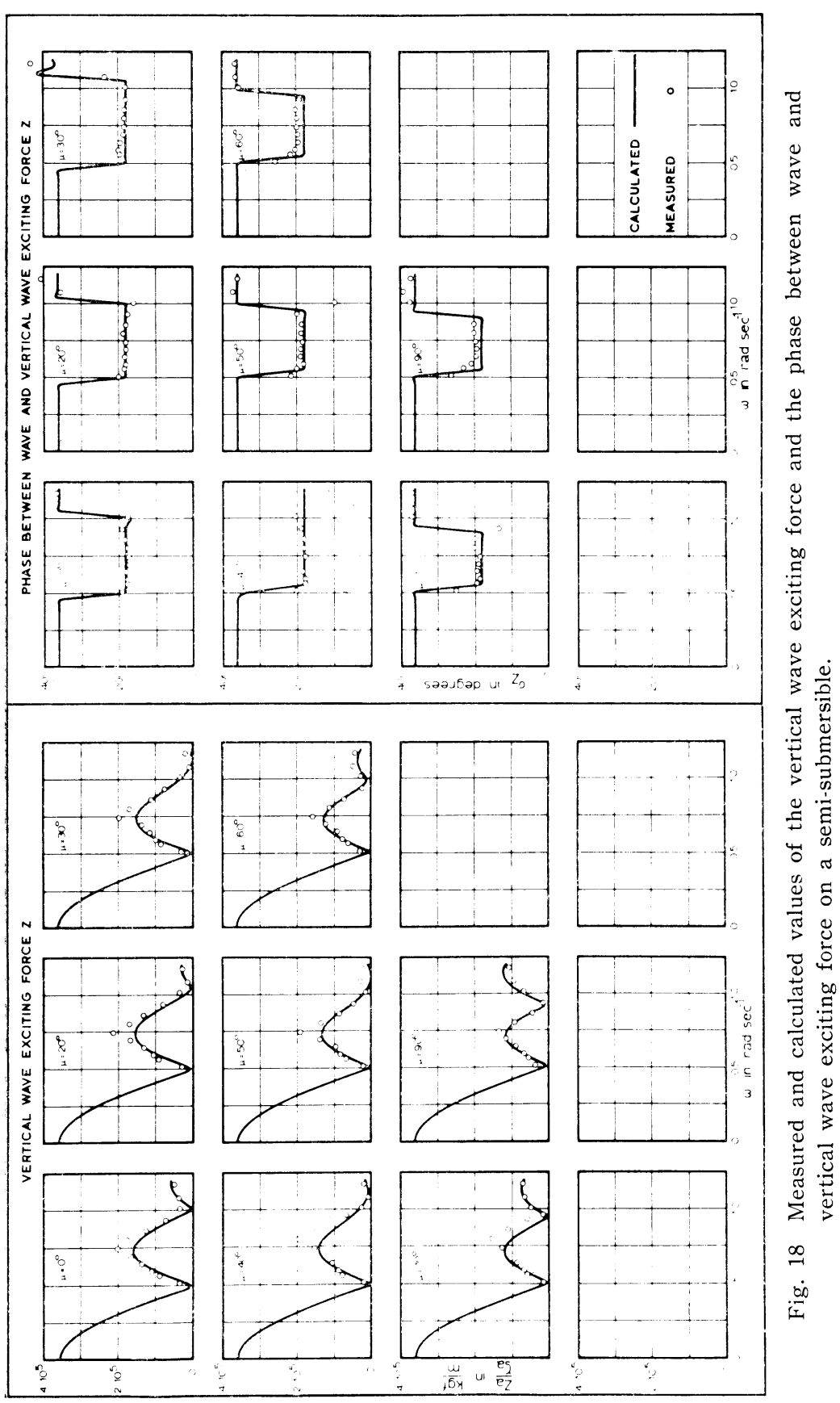


With respect to the manoeuvring of ships, different types of tests can be carried out as listed below.

-Determination of the effect of an increase in rpm combined with a rudder angle at low speed.

-Determination of the desirable width of a waterway (tests to include traffic simulation).

-Determination of the capacity of a bow thruster required for a special manoeuvre.

-Derivation of data for programming ships manoeuvres under various environmental conditions for application on a manoeuvring simulator.

In all these types of manoeuvring tests in the wave and current laboratory the ship's path is determined by a laser-system [45].

\section{The ship manoeuvring simu- lator}

The N.S.M.B. ship manoeuvring simulator, see Fig. 19, consists of three essential parts [46], as listed below.

-A wheelhouse with complete nautical instrumentation, see Fig. 20.

-A projection system consisting of a point light source, circular slides and silhouettes, and a circular projection screen, see Fig. 21.

-A hybride computer which can be programmed for any ship type with the aid of model test results (the

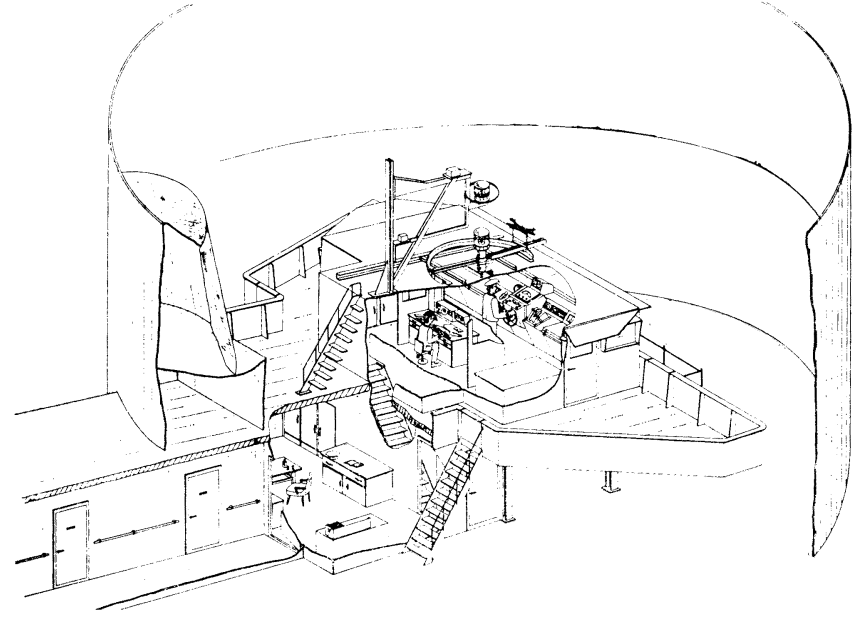

Fig. 19 Sectional perspective drawing of the manoeuvring simulator. necessary tests are carried out in the shallow water basin and wave and current laboratory), and full scale observations. This system offers the possibility to simulate ship manoeuvring on a full scale time base. In this way the human as-

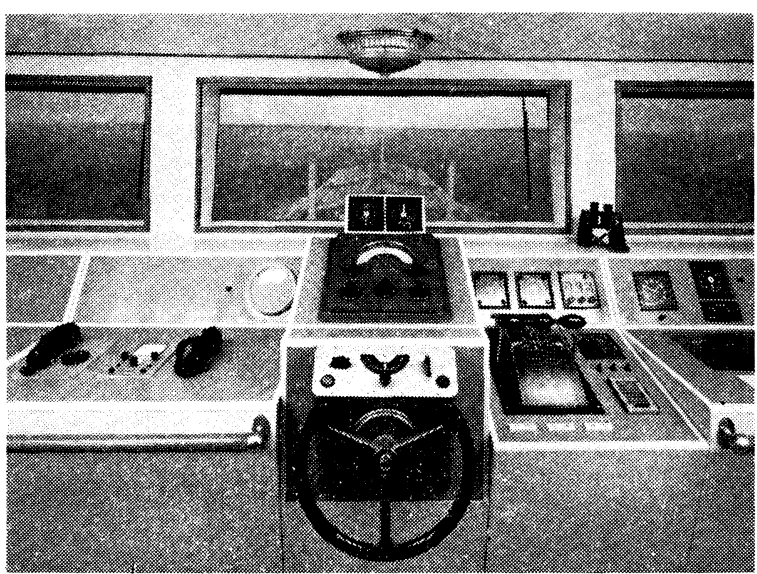

Fig. 20 View from the wheelhouse of the manoeuvring simulator.

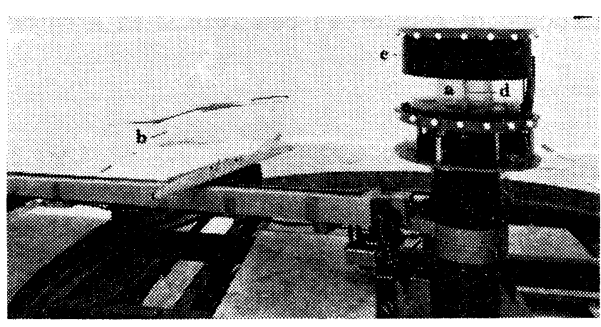

Projection system
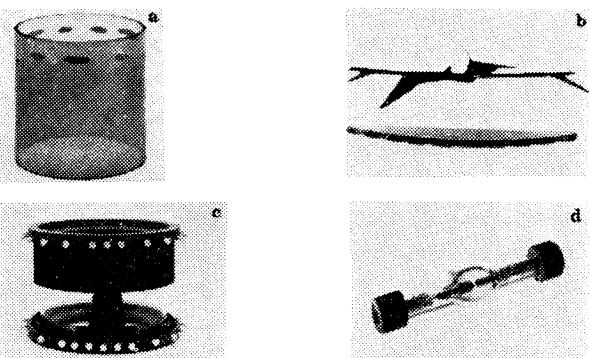

a) Sky drum

c) Sea drum

b) Object of shore

d) Comans arc lamp

Fig. 21 Projection system and its ele. ments. 
pect in manoeuvring can be taken into account.

After a one year experience on this manoeuvring simulator, the N.S.M.B. recognizes the following items for industrial service.

-Qualification of harbour designs with known ships and experienced pilots.

-Qualification of advanced ship designs from a viewpoint of ship handling and manoeuvring.

-Determination of the ship handling possibilities of non-existing large ships (500.000-1.000.000 tdw tankers).

-Design of traffic rules for waterways.

-Design of criteria to assist harbour authorities in their decision to give permission to ships to enter the harbour under known circumstances.

- The introduction of new nautical instruments.

-Training of pilots under non-experienced circumstances.

These types of industrial services may be delivered to new circles of future customers. It is clear that instruction and guidance by N.S.M.B. specialists are very important during the first acquaintances of new organizations interested in the possibilities of this three-dimensional ship manoeuvring simulator. The staff consists of hydrodynamic specialists, applied mathematicians and nautical experts.

\section{The depressurized towing tank (vacutank)}

In Fig. 22 an aerial view of the vacutank of the N.S.M.B., nearing its completion, in Ede is given. The inside dimensions of the tank are as follows:

$\begin{array}{lr}\text { length } & 240 \mathrm{~m} \\ \text { width } & 18 \mathrm{~m} \\ \text { depth } & 8 \mathrm{~m} .\end{array}$

When the tank is evacuated, the upper section or the roof must resist a pressure difference of about 1 atmosphere. Therefore, the upper section has been engineered as a cylindrical shell constructed of reinforced concrete with a thickness of $60 \mathrm{~cm}$. The pressure in the tank can be lowered

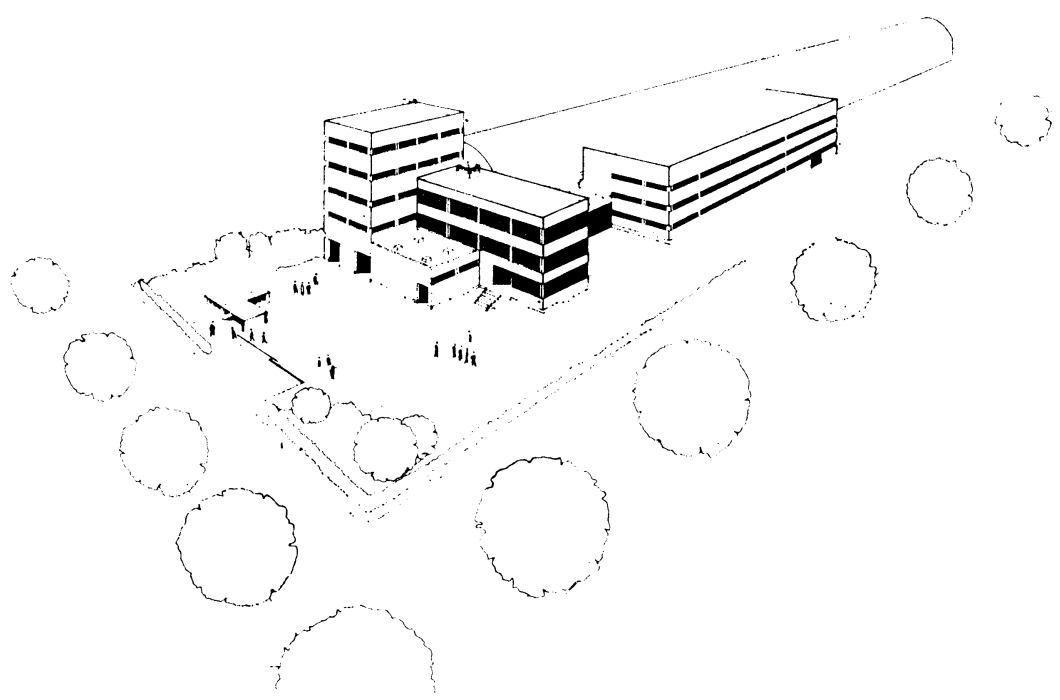

Fig. 22 Aerial view of depressurized (vacuum) towing tank. 
to 0.04 of an atmosphere in about 8 hours. Models of 12 meters in length, 2.40 meters in width and 18 tons in weight can be tested.

During the tests, the ship model is fitted to a towing carriage which can operate over the basin at speeds up to $4 \mathrm{~m} / \mathrm{sec}$. At a model scale of 33 , this means that ships with speeds up to about 45 knots can be investigated. The carriage is composed of cylindrical tubes of steel with a diameter of 2.5 meters and is operated by a cable driving system. The towing carriage weighs about 80 tons. The interior of the basin with the carriage and the cable driving system is shown in Fig. 23. The carriage, shown in Figs. 24 and 25, is equipped with a general purpose model support bridge. The carriage speed is controlled by a C.D.C. 1700 computer housed in an air-conditioned control room located in the office building at the front of the tank. Two or three men may be on board of the carriage in which normal atmospheric pressure will be maintained. The carriage can be connected to a lock located at the front of the tank which makes it possible for the personnel to enter or leave the carriage while the low pressure in the basin is maintained.

The general purpose instrumentation for the carriage is also housed in the control room. The construction of the carriage, the measuring equipment and the apparatus for transporting the models through a special lock in the basin and for fitting the model to the carriage are made such that most of the tests can be performed while maintaining the reduced pressure in the basin. The measuring equipment consists of a series of signal conditioning equipment compatible with all types of transducers and integral voltmeters of which the signals are directly converted to the C.D.C. 1700 computer in the control room by means of a curtain cable.

The observations of cavitation phenomena at the screw and of flow phenomena around the model can be performed through transparant parts of the hull of the model and through telescopes mounted under water outside the model. These observations can be reproduced in the control room by means of closed circuit television.

Although personnel may be on board of the carriage, the speed of the carriage and the model test-

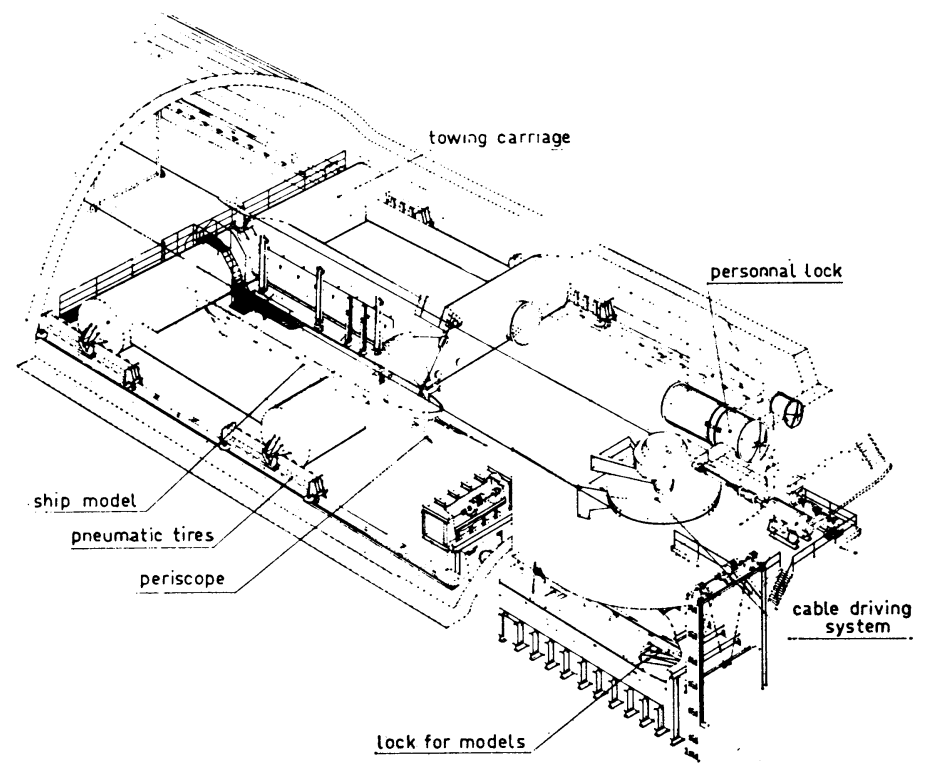

Fig. 23 Perspective drawing of the carriage and cable driving system of the depressurized towing tank. 


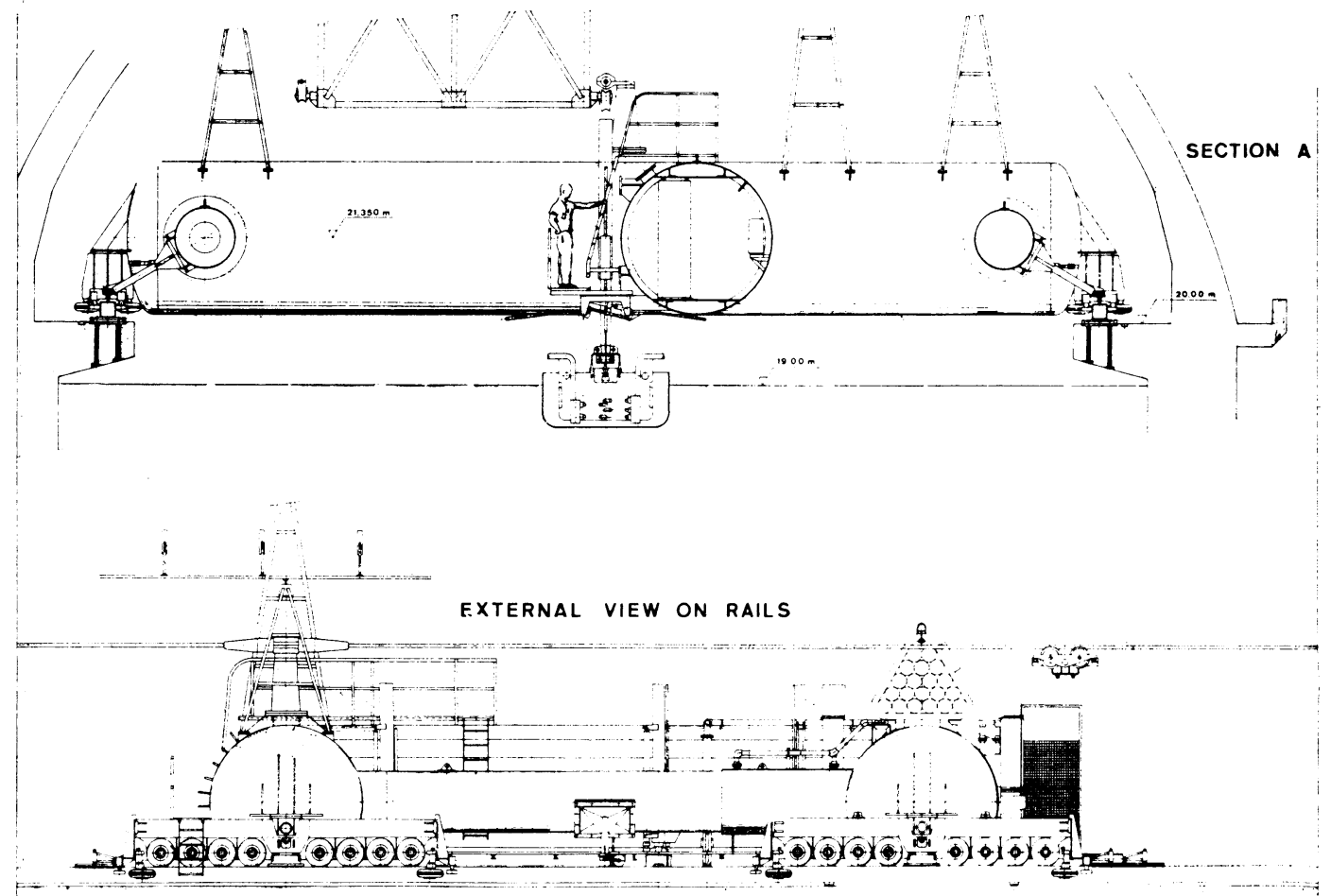

Fig. 24 Drawing of carriage of depressurized towing tank.

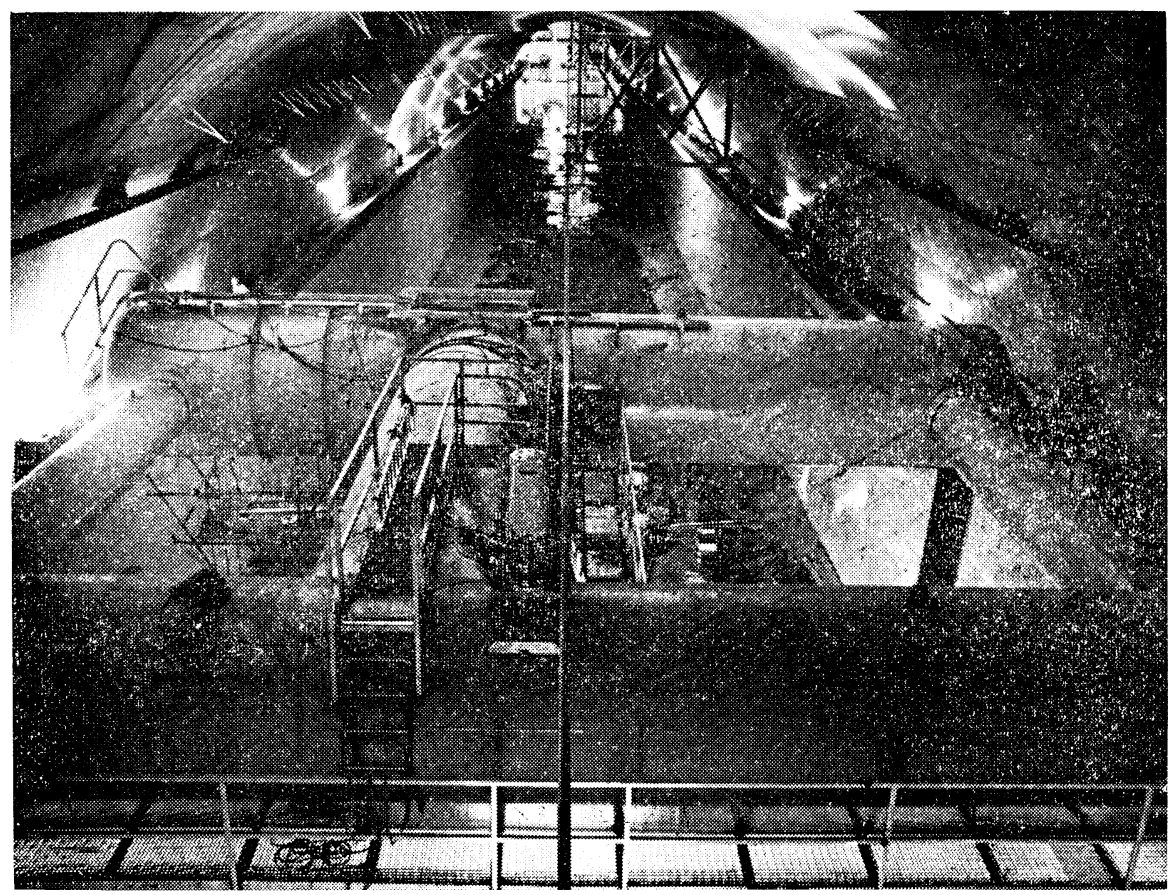

Fig. 25 Photo of the carriage after assembly. 
ing will be completely remotely controlled. To ensure the safety of the personnel on board of the carriage, many precausions have been made. The tank is fitted with a safety valve which makes it possible to pressurize the tank in a few minutes.

A new model-shop has been built next to the basin. This shop is well-equipped for the construction of glass reinforced plastic ship models up to a length of $12 \mathrm{~m}$. This material ensures operations under reduced pressure and has satisfactory strength. The propeller models are made at the work-shop in Wageningen. Most of the castings of the propeller models are finished by means of a numerically controlled milling machine. Various appendages such as rudders, bossings, shaft brackets and propeller nozzles will also be made at the work-shops in Wageningen.

The vacutank has been designed by Sogreah-Grenoble according to specifications in close co-operation with the N.S.M.B. The building was finished in July 1971 and the tank will be put into operation early in 1972 .

Photos of the vacutank on nearing completion (September 1971) are given in Figs. 26 and 27.

The vacutank will be used for experiments with models of seagoing ships under idealized conditions. This means that in the basin no wind, no waves and no current will be simulated. The dimensions of the model and the tank are such that the results of the tests may be considered to be applicable for ships in water of unlimited depth and width. The following types of investigations may be carried out:

- Model tests for the prediction of the performance of full size ships. An improvement in the reliability of the prediction is obtained due to the fact that now the effect of screw cavitation on propeller thrust and torque and on the interaction effects between screw and ship are taken into account.

- Model tests to determine the effect of different afterbody shapes and appendages and of different

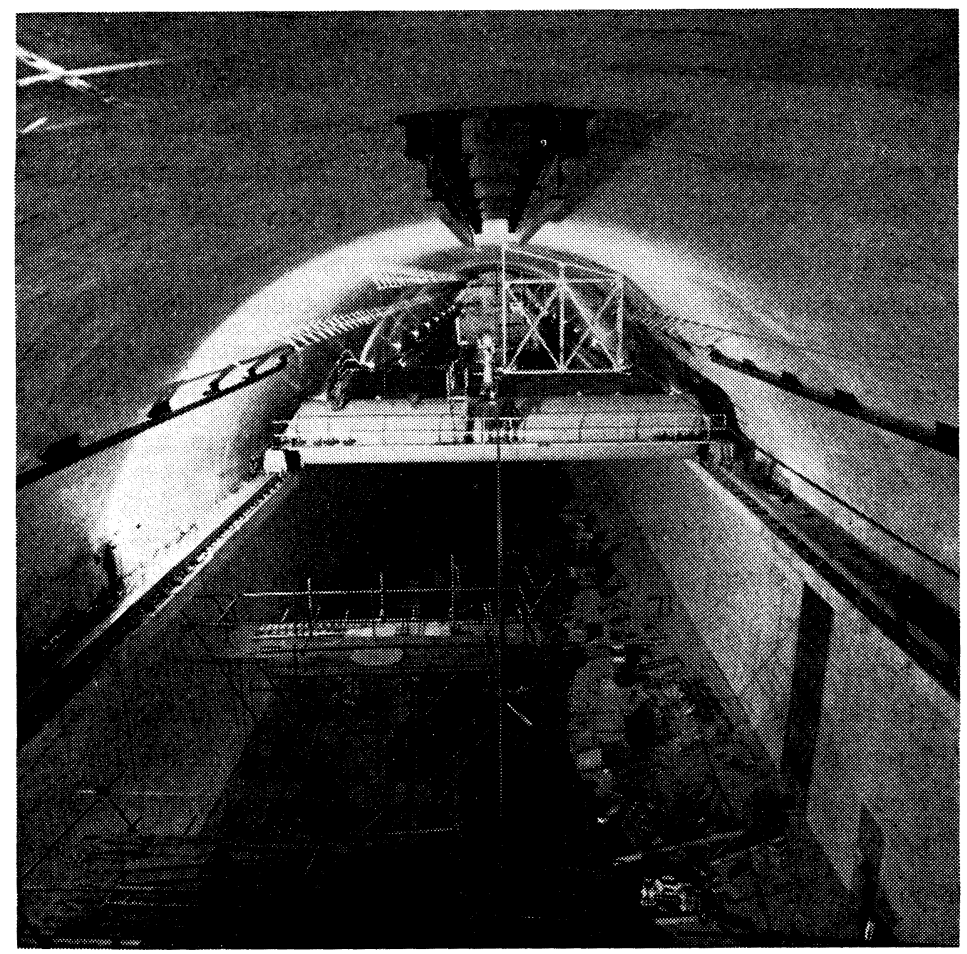

Fig. 26 Photo of interior of vacuum towing tank. 


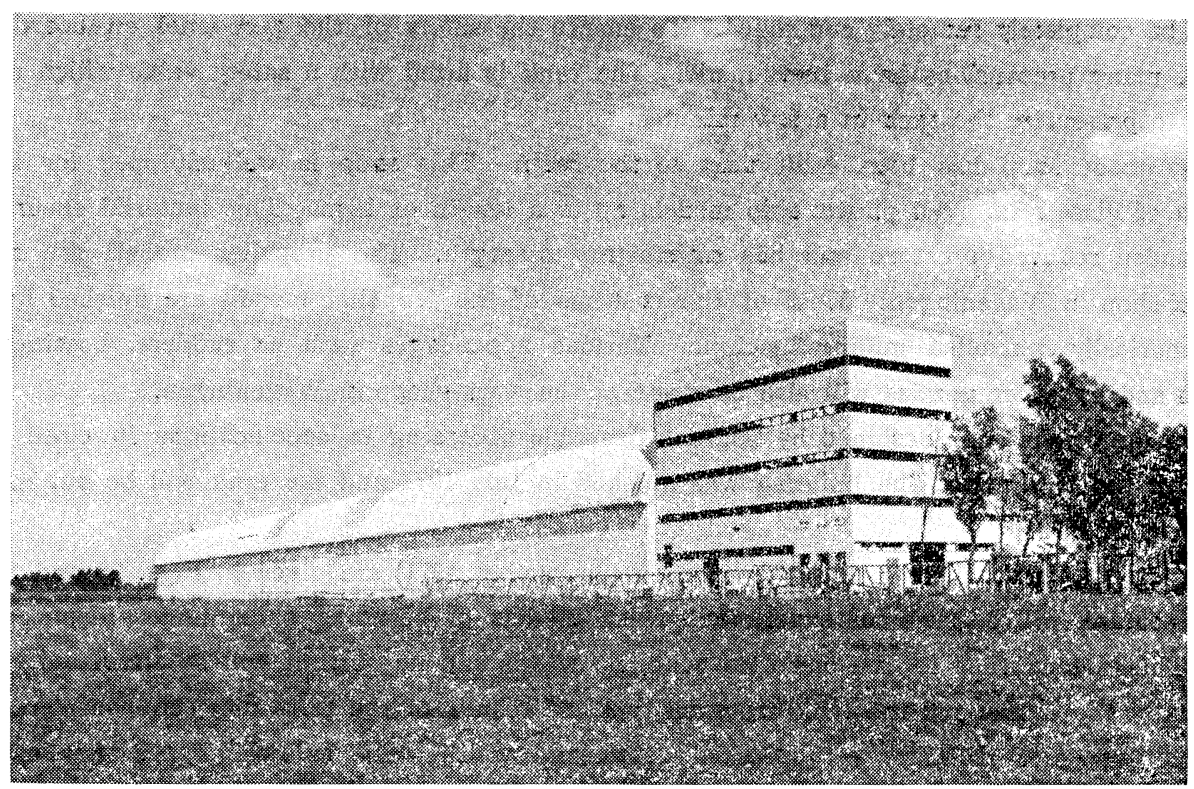

Fig. 27 Photo of vacuum towing tank nearing completion (September 1971).

propulsion devices and configurations of propulsion devices (screws, ducted propellers, overlapping screw propellers etc.) on the propulsion characteristics. The results of such tests may be strongly influenced by propeller cavitation.

- Model tests for the observation of propeller cavitation in order to predict the expected degree of safety against cavitation damage.

-Flow vizualization tests to determine whether undesired separation phenomena occur at the bow or stern of the model. Standard towing tank test techniques, in which the components of the frictional resistance and the wavemaking resistance are calculated separately, are not valid for models that suffer from extensive flow separation. They are only suitable for predicting the drag of ships which experience little separation drag. Here, tests can be performed to determine whether these unwanted phenomena take place.

-Wave breaking phenomena at the bow of the model can be studied. Recently another type of ship resistance, the so-called "wave breaking resistance" has been reported to occur at very full ships. This resistance can be significantly reduced or eliminated by a properly designed bow.

-Wake surveys for wake adapted propeller design and to determine in a more advanced way the different components of the ship's resistance.

-Model tests to determine the propeller induced vibratory forces including the effect of propeller cavitation. The vibratory forces acting on the propeller shaft are to be measured with a six com. ponent strain-gauge balance in the propeller shaft. The vibratory forces acting on the afterbody of the ship are to be measured by means of pressure pick-ups installed on the hull. Moreover, tests can also be carried out to determine the stresses in the blades of the screw propeller.

Besides these different types of investigations, this facility offers a means for acoustical research. The speed of the model at which propeller cavitation will first occur and the subsequent increase in the noise radiated by the screw propellers can be determined. Also, the noise spectrum of the screw propellers can be measured. Such investigations are of the utmost importance in order to qualify alternative designs of naval ships with respect to cavitation inception. speed. The provisions which have to be made in order to perform these acoustical measurements are still in study. 


\section{Final consideration}

This is more or less in a "nutshell" the history and development of a present-day industrial service institute for marine technology, the Netherlands Ship Model Basin.

In its strivings after a high scientific level of industrial service combined with relatively short delivery times and reasonable prices, an industrial service center, which has to operate on an independent base, has to look continuously for new fields of specialized service to the shipbuilding, shipping and offshore industry. Those specialized services must be of a nature making it unattractive or even impossible to perform them within the industry itself.

Apart from unique special purpose laboratories a very competent enthusiastic staff, continuously complemented with young talent is at least necessary for being successful in this fast growing technological world.

\section{References}

1) Kempf, G. and Foerster, E.: “Hydromechanische Probleme des Schiffsantriebs"; Teil I; Selbstverlag der Gesellschaft der Freunde und Förderer der Hamburgische Schiffbau-Versuchsanstalt, e.V., Hamburg, 1932.

2) Kempf, G.: "Hydromechanisch Probleme des Schiffsantriebs", Teil II; Verlag, R. Oldenbourg, 1940.

3) Proceedings of the summer meetings of the 75th session and International Conference on Experimental Tank Work; Institution of Naval Architects, London, July 10 to 13, 1934; Trans. Inst. of Naval Arch., 1934.

4) Lammeren, W.P.A. van: Resultaten van voortgezette systematische proeven met vrijvarende 4-bladige schroeven, type B4-40 en B4-55; Het Schip 19, no. 8 and no. 9, 1937; N.S.M.B. publication no. 38.

5) Lammeren, W. P. A. van, Manen, J. D. van and Oosterveld, M.W.C.: The Wageningen B-Screw Series; Society of Naval Architects and Marine Engineers; Vol. 77, 1969; N.S.M.B. publication no. 330.

6) Oosterveld, M. W. C. and Oossanen, P. van: "Further Computer Analyzed Data of the Wageningen B-Screw Series"; to be published.

7) Lammeren, W.P.A. van, Manen, J. D. van and Lap, A. J.W.: "Scale Effect Experiments on Victory Ships and Models ": Part I; Analysis of the resistance and thrust measurements on a model family and on the model boat D. C. ENDERT JR., International Shipbuilding Progress, Vol. 3, no. 18, 1956; N.S.M.B. publication no. 121 a.

8) Manen, J. D. van and Lap. A. J. W.: "Scale Effect Experiments on Victory Ships and Models"; Part II; Analysis of the Wake Measurements on a Model Family and the Model Boat D. C. ENDERT JR., International Shipbuilding Progress, Vol. 5, no. 47, 1958; N.S.M.B. publication no. 147.

9) Lap, A. J. W. and Manen, J. D. van: "Scale Effect Experiments on Victory Ships and Models"; Parts III and IV; International Shipbuilding Progress, Vol. 8, no. 81, 1961; N.S.M.B. publication no. 197.

10) Lap, A. J. W. and Troost, L.: "Frictional Drag of Ship Forms"; Bulletin of the Soc. of Naval Architects and Marine Engineers, Vol. VIII, no. 2, 1953.

11) Lap, A.J.W.: "Diagrams for Determining the Resistance of Single-Screw Ships"; International Shipbuilding Progress, 1954.

12) Oortmerssen, G. van: "A Power Prediction Method and its Application to Small Ships"; to be published.

13) Manen, J. D. van: “Open-Water Test Series with Propellers in Nozzles"; International Shipbuilding Progress; Vol. 1, no. 2, 1954; N.S.M.B. publication no. 115a.

14) Manen, J. D. van: "Recent Research on Propellers in Nozzles"; International Shipbuilding Progress, Vol. 4, no. 36, 1957; N.S.M.B. publication no. 136.

15) Oosterveld, M.W.C.: “Wake Adapted Ducted Propellers"; Doctor's Thesis, 1970, N.S.M.B. publication no. 345.

16) Muntjewerf, J. J.: "Methodical Series Experiments on Cylindrical Bows"; Trans. Inst. of Naval Architects, Vol. 112 , no. $2,1970$.

17) Muntjewerf, J. J.: “Cylindrical Bows"; Jubilee Memorial "W.P.A. van Lammeren 1930-1970", 1970.

18) Manen, J. D. van: "Bent Trailing Edges of Propeller Blades of High Powered Single Screw Ships"; N.S.M.B. publication no. 215; International Shipbuilding Progress, 1963.

19) Wijngaarden, L. van: "On the Collective Collapse of a Large Number of Gas Bubbles in Water"; 11th International Congress of Applied Mechanics, Munich, Germany, 1964, Proceedings, 1966.

20) Walle, F. van der: "On the Growth of Nuclei and the Related Scaling Factors in Cavitation Inception"; 4th Symposium on Naval Hydrodynamics, Washington D.C., 1962.

21) Meulen, J.H. J. van der: "Cavitation on Hemispherical Nosed Teflon Bodies"; I.U.T.A.M. Symposium on NonSteady Flow of Water at High Speeds, Leningrad, 1971.

22) Meulen, J. H. J. van der: "Cavitation Erosion of a Ship Model Propeller"; Characterization and Determination of Erosion Resistance, ASTMSTP 474, American Society for Testing Materials, 1970.

23) Oossanen, P. van: "Profile Characteristics in Cavitating and Non-Cavitating Flows"; International Shipbuilding Progress, 1971; S.N.M.B. publication no. 369.

24) Oossanen, P. van: "A Method to Minimize the Occurance of Cavitation on Propellers in a Wake"; International Shipbuilding Progress, 1971; N.S.M.B. publication no. 388. 
25) Sparenberg, J. A.: “Application of Lifting Surface Theory to Ship Screws"; Proceedings of "Kon. Ned. Akademie van Wetenschappen", Amsterdam, Series B, 62, 1959.

26) Sparenberg, J. A.: " Note on the Ship Screw in an Inhomogeneous Field of Flow"; N.S.M.B. Memo, 1962.

27) Kuiper, G.: "Some Preliminary Results of an Exact Treatment of the Linearized Lifting Surface Integral Equation"; "Workshop on Lifting Surface Theory in Ship Hydrodynamics", Cambridge, Mass., 1969.

28) Manen, J. D. van: “The Effect of Cavitation on the Interaction between Propeller and Ship's Hull"; I.U.T.A.M. Symposium on Non-Steady Flow of Water at High Speeds, Leningrad, 1971.

29) Oossanen, P. van and Kooy, J. van der: "Vibratory Hull Forces Induced by Cavitating Propellers"; to be published.

30) Wereldsma, R.: "Experimental Determination of Thrust Eccentricity and Transverse Forces, Generated by a Screw Propeller"; International Shipbuilding Progress, Vol. 9, 1962.

31) Wereldsma, R.: "Some Aspects of the Research into Propeller Induced Vibrations"; International Shipbuilding Progress, Vol. 14, no. 154, 1967; N.S.M.B. publication no. 278.

32) Wereldsma, R.: “Dynamic Behaviour of Ship Propellers"; Doctor's Thesis, N.S.M.B. publication no. $255,1965$.

33) Hylarides, S.: "Ship Vibration Analysis by Finite Element Technique"; Parts I and II; Reports no. 107S and 153S of the Netherlands Ship Research Centre TNO, 1967 and 1971 respectively.

34) Symposium on a Restricted Draught Tanker, Netherlands Ship Model Basin, 1971, Wageningen; to be published.

35) Vossers, G., Swaan, W. A. and Rijken, H.: "Experiments with Series 60 Models in Waves"; N.S.M.B. publication no. 184; International Shipbuilding Progress, Vol. 8, 1961; Trans. Society of Naval Architects and Marine Engineers, Vol. 68, 1960.

36) Vossers, G.: "Resistance, Propulsion and Steering of Ships, Part C, Behaviour of Ships in Waves": Technical Publishing Co. H. Stam, Culemborg, Holland, 1962.

37) Swaan, W. A.: "Amidship Bending Moments for Ships in Waves"; International Shipbuilding Progress, Vol. 6, 1959.

38) Verhagen, J. H.G.: “The Impact of a Flat Plate on a Water Surface”; Journal of Ship Research, Vol. 11, 1967.

39) Sluijs, M. F. van: "Vertical Ship Motions and Deck Wetness"; Spring Meeting, Society of Naval Architects and Marine Engineers, May 1969.

40) Witte, J. H.: "Predicted Performance of Large Water Ramjets"; A.I.A.A. paper no. 69-406, 1969.

41) Lammeren, W.P.A. van and Lap, A. J.W.: “The Shallow Water Laboratory of the Netherlands Ship Model Basin at Wageningen"; International Shipbuilding Progress, Vol. 6, 1959; N.S.M.B. publication no. 156a.

42) Hooft, J. P.: “On the Critical Speed Range of Ships in Restricted Waterways"; International Shipbuilding Progress. Vol. 16, 1969; N.S.M.B. publication no. 324.

43) Lammeren, W.P. A. van and Lap, A. J. W.: "The Combined Wave and Current Laboratory of the Netherlands Ship Model Basin"; International Shipbuilding Progress, Vol. 11, 1964.

44) Hooft, J. P.: "A Mathematical Method of Determining Hydrodynamically Induced Forces on a Semi-Submersible"; Annual Meeting of the Society of Naval Architects and Marine Engineers, 1971.

45) Loesberg, P. P.: “Model Navigator Based on Laser"; International Shipbuilding Progress, Vol. 16, 1969.

46) Manen, J. D. van and Hooft, J. P.: “A Three Dimensional Simulator for Manoeuvring of Surface Ships"; International Shipbuilding Progress, Vol. 17, no. 194, 1970. 


\section{Summary of Discussions to "Scientific Industrial Service in Marine Technology"}

Dr. K. Yokoo asked:

(1) further explanation on Fig. 5,

(2) the rate of operation of each facility and

(3) how the scale effects are considered which cannot be eliminated though cavitation may be simulated in the vacutank.

Prof. van Manen replied:

(1) Fig. 5 is an example of the testresults showing the effect of surface condition capilarity etc. on desinent cavitation number. Teflon was selected as an extreme case for such a basic research.

(2) In average for 1971, deep water basin:-16-20 hours/day, cavitation tunnels:-2-3 days/ week, seakeeping laboratory:-16-20 hours/day, shallow water basin:-8 hours/day, wave and current lab.:-8 hours/day.

(3) Using models having about $24 \mathrm{~cm}$ diameter propeller, we shall be able to avoid serious error in simulating cavitation and in turn measuring propeller vibratory forces. There are scale effects, but we then have model data which can be extended to full scale with reasonable methods.

Dr. Y. Yamanouchi and Dr. K. Yokoo asked:

how the construction of a vacutank was initiated.

Prof. van Manen replied:

According to the experiences in the towing tank and the cavitation tunnels $24 \mathrm{~cm}$ propeller diameter is a minimum to obtain reliable test results. The size of the ship models and in turn the size of the tank were calculated. The costs of building a towing tank and a cavitation tunnel with free surface were compared with the construction of a towing tank with the same capability which can be evacuated. The vacutank turned out to be much more economical.

The vacutank has been designed to achieve a minimum static pressure of $0.04 \mathrm{~kg} / \mathrm{cm}^{2}$. Subtracting the vapour pressure $0.02 \mathrm{~kg} / \mathrm{cm}^{2}$, we have $p-e=0.02 \mathrm{~kg} / \mathrm{cm}^{2}$. When testing the models in accordance with Froude's law, the scale in the pressure in proportional to length scale, so that a $600 \mathrm{~m}$ ship can be tested using a $12 \mathrm{~m}$ model.

Mr. S. Nishiyama asked:

(1) how to keep the air content in water under low pressures and

(2) whether the water boils at about $30^{\circ} \mathrm{C}$ when testing around the minimum pressure.

Prof. van Manen replied:

(1) The air content will be controlled by adding air into water.

(2) The water temperature in the tank is about $12^{\circ} \mathrm{C}$ on the average, so we are not afraid of the cold boiling of water.

Prof. S. Motora asked:

(1) how the seakeeping tests are carried out in irregular waves and

(2) how much is the annual running cost, and how much is spent for the research works. 
Prof. van Manen replied:

(1) The tests in irregular seas are carried out in the seakeeping laboratory. The snake type wave makers are operated with signals corresponding to irregular seas. We use standard spectra. The behaviour of ships in other spectra are calculated by the transfer function on the computer.

(2) For these years the total income is about 14 million Hfl. per year and the total cost is about 12 million Hfl., the difference being paid for the debt, instrumentation and small extensions. About 2 million Hfl. are spent for our own research works.

Mr. T. Ito asked:

(1) further explanation on Fig. 6 and

(2) difficulties in preparing the instrumentation for the vacutank.

Prof. van Manen replied:

(1) The rate of weight loss due to cavitation increases in the beginning because of formation of pits and then decreases. In the third stage the rate remains constant when the tests are made with a magnetostrictive or an ultrasonic apparatus. The present results, however, show an increase again. Small parts of the propeller blades fall off bent trailing edges, which does not occur in other test apparatuses.

(2) Observation of propeller cavitation in the vacutank is one of the problems to be dealt with. The afterbody is shaped by transparent perspective so that the light is duly supplied. The number of revolutions is about 10 per second. The cavitation pattern is recorded by Ampex video tape recorder and reproduced with faster speeds. The pressure gages for the measurement of vibratory forces should be airtight. The gages are being developed in the NSMB. A 6-component balance is being prepared by us. 